\title{
Theologization of Greek Terms and Concepts in the Septuagint and New Testament
}

\author{
FRANCISZEK MICKIEWICZ \\ Cardinal Stefan Wyszyński University in Warsaw \\ fmickiewicz@o2.pl; ORCID: 0000-0003-3945-8169
}

\begin{abstract}
Hellenistic literature, having great achievements in the fields of philosophy, drama, and poetry, did not know the theological concepts and issues which underlie the texts contained in the Hebrew Bible. So when the creators of the Septuagint, and then also the authors of the New Testament, used the Greek language to convey God's inspired truths to the world, they were forced to give secular terms a new theological meaning, frequently choosing neutral words for this purpose, not burdened with negative associations. With their translation work, they built a kind of bridge between Hellenic and Jewish cultures. On the one hand, the Septuagint allowed Jews reading the Bible in Greek to remain connected not only with the religious heritage of their fathers, but also with the cultural values that were closely related to that language and its world. In turn, for the Greeks, who after some time began to appreciate this work and gained knowledge of its content, it opened vast horizons of new religious and spiritual values, which until then were completely alien to them. The work of the authors of the Septuagint was continued and developed by the authors of the New Testament, which added to their theological output many new religious and moral values arising from the teaching of Jesus Christ. That way they contributed considerably to the development of the Koinē Greek and significantly transformed the spiritual life of the people speaking the language.
\end{abstract}

Keywords: Septuagint, theology of the Old and New Testaments, Biblical Greek, hellenistic culture

Many scientific publications mention the influence which Hellenic culture had on the understanding and interpretation of the content contained in the Hebrew Bible. Its role in enriching the biblical language with Greek concepts, hitherto unknown to Jewish writers, is obviously very important and is still not sufficiently researched. It should be noted, however, that these works primarily show the influence of the broadly understood Hellenic culture on the Holy Bible. Meanwhile, a careful analysis of the biblical text draws conclusions that also the theological thought of the authors of the Old and New Testaments changed the original meaning of many important Greek terms and concepts, and thus, significantly enriched Hellenic culture with religious and moral ideas hitherto unknown to it. This article aims to elaborate the topic of Hebrew and Christian theological culture contribution to the development and significant transformation of Hellenic thought and spirituality. 


\section{The Causes and Effects of the Theologization of Greek Terms in the Septuagint}

During the Ptolemaic reign in Egypt, there was a rapid development of the Alexandrian Jewish diaspora which was possible due to the privileges equating the Jews living there with Macedonians and Greeks. Although they had a strong sense of their own identity, zealously nurturing their native traditions and maintaining a separate ethos based on the Mosaic Law, they were nevertheless fascinated with Hellenic culture and willingly took over from it everything which was not contrary to their religious beliefs. One of the elements of their openness to the domination of Hellenism was the abandonment of the Aramaic language, as evidenced, for example, by the fact that all Jewish texts, which were written in Alexandria since the third century BC, were compiled in Greek. ${ }^{1}$ At that time, the religious life of Jews from the aforementioned diaspora was already focused on the synagogue, whereas the main element of the liturgy celebrated there was the reading of the Law, and later also the Prophets. Those whose grasp on the biblical language was weakening expressed the need to have the holy books in a language they could understand. They were even convinced that further maintenance of their own identity, persistence with the ethical norms established centuries ago, and further deepening of personal piety, called for translating Hebrew books into Greek. ${ }^{2}$

Of course, the Greek translators of the Hebrew Bible did not invent the very idea and art of converting a text in one language into another. In the countries of the Middle East, multilingual documents had been used for a long time, and well-educated royal scribes had to know even several languages. Also, in the ancient Mediterranean world (in Greece, Rome and Egypt) administrative documents, lists of merchandise or minor literary works were translated. None of these translations, however, concerned religious content, or involved a text as extensive as the one constituted together by the books of the Law, the Prophets, and other Scriptures. ${ }^{3}$ Greek writers did not create any translation patterns either. Convinced of the unsurpassed superiority of their culture, they did not feel the need to translate the works of other nations into their own language, and thus did not create anything worthy of being called translation theory. ${ }^{4}$ For this reason, it should be concluded that the translation of the entire Hebrew Bible into Greek was a completely new and unique phenomenon in the ancient world at that time, and the very fruit of this work - the Septuagint was the greatest achievement of Hellenistic Judaism and testifies to the high intellectual and religious level of the Jews living in the capital of the Ptolemaic Kingdom. ${ }^{5}$

\footnotetext{
Cf. Jędrzejewski, "Septuaginta," 253-255.

Cf. Jędrzejewski, "Septuaginta," 256.

Cf. Law, When God Spoke Greek, 34-35.

Cf. Piętka, "Antyczna translatologia," 9-11.

Cf. Law, When God Spoke Greek, 35.
} 
With virtually no scientific rules of translation at their disposal, the Jewish scholars approached their task very simply. They relied on the assumption that the most important matter for them was to preserve the spirit, content and sense of the original Hebrew version. Thus, when translating biblical texts, they often adapted the syntax of the Greek language and the original meaning of its words to the Hebrew syntax and terminology. ${ }^{6}$ As a result - according to the linguists - they did not convey their religious tradition in a refined form of classical Greek and, unfortunately, did not make their work a showcase of the best Greek literature. They rather created a distinctive language of the Septuagint, which is highly different from the literary language, and is similar to the koine version used in colloquial speech and filled with many Semitisms. ${ }^{7}$

Hebrew and Greek belong to completely different language families. The social as well as cultural and religious horizon of the Hebrew Bible significantly differs from the mentality of the Hellenistic world people. This was already noted by the author translating the Hebrew Wisdom of Sirach. Attempting to justify all the defects and imperfections of his work, he stated in the Prologue that "words read in Hebrew do not have the same power as when translated into another speech" (vv. 21-22). This discrepancies between cultures and languages frequently caused many difficulties for translators. Thus, not knowing any scientific theory of translation, they copied a typically Semitic way of speaking into Greek. Also, whenever they did not find a suitable word in Greek to express Hebrew terms, they considered them untranslatable and borrowed them in their original version, writing in Greek letters (e.g., gabis, cheroubim, serafin, pascha, sabbata, siklos and others). ${ }^{8}$ However, when they noticed that Hebrew and Greek had analogous words with a slightly different semantic scope, they had to make a well-thought-out choice, using the same Greek term to represent different Hebrew words, or vice versa: employing different Greek terms depending on the context to represent the same Hebrew word. ${ }^{9}$

The creators of the Septuagint encountered the greatest difficulties in the field of monotheistic faith and morality, which happened to be the most important for them since it was not only the leading theme, fabric and foundation of all biblical texts, but also the main cause and purpose of their writing. Unfortunately, the Greek language did not contain such religious concepts as the ones contained in the Hebrew Bible, and the Greek thinkers themselves did not know theology in the strict sense of the word. It is true that they sometimes used the verb theologein, but they understood it as "talking about gods," or "telling myths about gods," and therefore a "theologian" for them was a poet who wrote poems and hymns about deities. On the other hand,

\footnotetext{
Cf. Rajak, Translation and Survival, 62-63; Ehrensperger, "Speaking Greek Under Rome," 21.

This was noticed by, e.g., Adolf Deissmann (Bible Studies). Regarding this, cf. Lust, "Translation Greek," 110-111; Joosten, "Pillars of the Sacred," 2-4.

Cf. Joosten, "Pillars of the Sacred," 5; Lust, "Translation Greek," 111 and 119.

This matter is more broadly elaborated on in Harl, "La «Bible d'Alexandrie»," 325.
} 
the stoics, contemporaneous with the authors of the Septuagint, regarded theology as a process of discussing phenomena concerning the gods based on allegorical commentaries of the works of Homer and other poets. ${ }^{10}$ Such "theology" had nothing to do with the biblical story of God, truly accompanying the chosen people, as well as with revelation preserved on the pages of the Holy Bible, with its effects influencing all areas of human life, and with the specific worship practiced first in various Jewish temples, and then in one temple in Jerusalem.

On this occasion, it is worth noting that when the Greek infinitive theologein, which can be translated as "theologize," is preceded by a neuter article, it becomes a noun, which in turn can be translated in two ways: as "theologizing" or "theologization." These two nouns have different meanings. Similarly, to philosophizing, which means practicing philosophy, theologizing (used very rarely) means practicing theology, theological thinking, and theological reflection on the matters of faith. On the other hand, theologization denotes giving theological meaning to terms, concepts, specific scientific disciplines or even entire areas of human life, which until now had a purely secular meaning. Even though this term has not been fully accepted in the dictionaries of the Polish language, it appears quite often in scientific studies. ${ }^{11}$

This distinction becomes valid when we contemplate the translation work of the Septuagint authors. When they had to translate into Greek the names or concepts closely connected to their customs and monotheistic religion, which were at the same time completely foreign to Hellenistic culture and religion, they searched their dictionary for Greek terms that would fit best the reality described in the Hebrew Bible. In order to achieve their goal, they had to theologize these terms, which means that they had to impart a new theological meaning to them, one transferred from the biblical world, ${ }^{12}$ which Greek readers could recognize only after a deeper reflection, or even after an in-depth analysis of the context in which these words appeared. There are many instances of such development of the Greek language and the manner in which the domain of religion enriched it. Among them, the following are worth distinguishing:

agape - lack of this word in extra-biblical Greek; in the LXX: "love"; angelos - a herald, a messenger, a courier; in the LXX: an angel, God's messenger; diathēke - managing property, a will, a contract; in the LXX: a covenant meaning the undertaking of specific commitments by two parties: God and the people;

10 Cf. Bielawski, Mikroteologie, 13-14.

11 See e.g. Mazurkiewicz, “Teologizacja narodu," 267-276; Poniży, "Logos w Księdze Mądrości," 75-92; R. Sobański, "Wprowadzenie do zagadnienia roli prawa w Kościele," 3-4 (the author of the paper considers, among others, the problem of the theologization of canon law); Szydłowski, "Teologizacja pedagogiki," $210-216$.

12 Cf. Joosten, "Pillars of the Sacred," 6-14. 
doksa - an opinion, glory, fame, honor; in the LXX: glory, reputation, the glory of God - revealed as a dazzling light that expresses the excellence of His spiritual nature;

ekklesia - a people's assembly; in the LXX: the convocation for the worship of God; eleos - pity, compassion; in the LXX: compassion, kindness, mercy, an act of love; eulogeo - to speak well, praise; in the LXX: to bless;

hamartano and hamartia - to miss and missing a target; in the LXX: to sin and a sin; pistis - trust, reliability, honesty; in the LXX: belief in God or faithfulness;

pneuma - wind, air, a breath, a breath of life, a living being; in the LXX: also, the Spirit of God.

Even this short compilation leads to the conclusion that the broadening of the semantic field of many Greek terms with theological field is not only a valuable contribution to the Hellenistic culture. The translation, faithfully reflecting the religious spirit of the source text, also made the Jewish community aware that God, who once spoke Hebrew through the prophets, now wished to speak to mankind in Greek ${ }^{13}$ and wished to convey to them His Law, showing them the way to attaining righteousness. However, this new consciousness slowly gave rise to the belief that God desires the salvation not only of His chosen people, but of all the peoples in the world.

\section{Reasons for Theologization of Greek Terms in the New Testament}

What has been mentioned above presents yet another priceless value of the Septuagint, notably the fact that it prepared the Greek-speaking Jewish and pagan people for the acceptance of the New Testament message. ${ }^{14}$ When the apostles of Christ started to proclaim their message to the world, both in the Jewish community (speaking in Aramaic) and in the Greek community, they first felt the need to prove that it was Jesus of Nazareth who was promised by God, announced by the prophets and awaited for centuries as Savior (see e.g., Acts 3:18-26; 10:43; 13:32-41). Therefore, for apologetic purposes they referred to the Law and the Prophets, providing evidence that these scriptures attain their fulfillment in Him. When they used Greek in their speeches, they no longer had to translate the Old Testament texts themselves, but they could use a translation that was familiar to Jews in the diaspora and to the proselytes who sympathized with them and God-fearing people. From it, they could also learn a theological language that enabled them to convey important facts about God's

13 This truth is emphasized by the titles of the publications: Law, When God Spoke Greek; Chrostowski, "Gdy Bóg przemówil po grecku," 60-70.

14 Georg Bertram ("Praeparatio Evangelica," 225-249) wrote about it extensively and considered many aspects of the issue. 
redemptive work. ${ }^{15}$ This language was also used later on in the works of Evangelists who even imitated the style of the Septuagint (of which St. Luke is an outstanding example) in order to highlight the continuity between the Old and New Testaments. ${ }^{16}$

Nevertheless, the early Christians, drawing on the authority of Jesus (see particularly Matt 9:16-17; John 4:21-24), were also from the very beginning aware of the novelty of the Gospel received from Him, which could not be fully expressed in the old categories of the language used so far in the Hellenistic world. Obviously, the pagans of that time were also familiar with the religious vocabulary, as was demonstrated by the inscriptions of that period consisting of confessions or propitiation texts. It is possible to find terms expressing the religious idea of guilt, punishment and penance, such as syneidèsis ("consciousness"), kolasis ("punishment"), apallassōo ("to liberate"), eksilaskomai ("to appease"), or dynamis ("power") but the idea of salvation, which is the main theme of the entire Scriptures, is clearly missing. ${ }^{17}$ It is true that St. Paul sometimes imitates catalogs of vices and virtues known in Greek literature (e.g., Rom 1:26-31; 1 Cor 6:9-10 and others), using the terminology coined by the Stoics, adopts the idea of the natural law (especially in Rom 2:14-16) and consciousness (Rom 13:5; 1 Cor 10:25-29). However, in-depth research demonstrates that neither the Apostle of the Nations nor other New Testament authors accepted the theological and anthropological foundations of Stoicism, among which there were, for example, the science of cosmic reason (logos) the idea of the soul of the world (pneu$m a)$, neither did they directly refer to pagan religious texts, ${ }^{18}$ as their content had nothing to do with evangelical spirituality and Jesus' teaching about the kingdom of God. Furthermore, the aim of their teaching was not to show Christian worship as a better form of pagan cults, but to proclaim the Gospel about the salvific work of Jesus Christ, with which a completely new way of serving God is associated. For that reason, as can be concluded from an attentive analysis of New Testament religious vocabulary, they knowingly avoided terminology closely connected to pagan cults, and while using more neutral terms, they were often obliged to adapt the original meaning of the terms to their Gospel message. ${ }^{19}$

There are certainly more cases of such theological work in the New Testament epistles than in the gospels. However, while much of the Gospel text consists of the accounts of Jesus' life and activity, the epistles of St. Paul and the other apostles give first and foremost a theological reflection based on the teaching of Christ, which

15 Cf. Mohrmann, "Linguistic Problems," 22.

16 It was emphasized by, among others, Tabachovitz, Die Septuagint. Regarding this, cf. Roberts, "The Language Background," 198.

17 Colin J. Hemer elaborates this subject in "Reflections on the Nature," 85-88.

18 A broader approach to this subject can be found in: Mickiewicz, Teologiczna etyka Świętego Pawła, 30-35.

19 Cf. Nock, "The Vocabulary of the New Testament," 134-139. When St. Paul at the Areopagus tried to prove that the God of the Bible was just the one whom the Greeks had so far worshiped as the "Unknown God" (Acts 17:23ff), his arguments were not successful. 
was a radical novelty both for the Jews of that time and for pious pagans, and also required the use of a new religious language. Despite this, the authors of the New Testament rarely introduced new words into the then-known Greek vocabulary (such as the word charisma, probably coined by St. Paul; empaigmone- - "mockery" in 2 Pet $3: 3$ or parafronia - "insanity" in 2 Pet 2:16). On the other hand, they more often gave commonly used words a new theological meaning. In this way, words such as doksa ("good name," "glory") or dikaios ("righteous") have acquired a deeper meaning associated with biblical revelation, although they are often still used in the old sense as well. It also happens that one form of the root (such as kal-) continues the older meaning (verb kaleō - "to call," "to summon"), while its other forms take special, strictly religious meanings (nouns klēsis - "calling," kletos - "called"). Some of these new meanings have already originated in the Septuagint, while the others are entirely new. ${ }^{20}$ This deepening or even change of the original meaning is clearly visible in such words like:

adelfos - brother; in NT: a member of the Christian community;

baptidzō, baptō, baptisma - to immerse, immersion, in the NT: to baptize, baptism; ekklessia - people's assembly, in NT: Church, community of believers in Christ;

euangelion - good news; in the NT: Christ's teaching about salvation as good news; cosmos - order, peace, decoration, universe; in the NT: heaven and earth, the human

world tainted by sin, but an object of God's love, and redeemed by the Son of God; lytron - redemption of a slave; in the NT: redemption that defines the salvific work of Christ;

oikonomia - home management; in the NT: God's saving plan;

peirasmos - trial; in the NT: Satan's trial or temptation (persuasion) to do evil (some texts also retain the original meaning);

sōtêr - savior, deliverer, in the LXX: God the Savior, and in the NT: Jesus Christ the Savior in a purely spiritual sense;

eunouch and eunouchidzō - eunuch (to castrate), in Matt 19:12 refers to a man who voluntarily renounces marriage and conjugal life.

\section{Examples of Theologization of Greek Terms in the Septuagint and the New Testament}

After this general introduction to the subject matter, it is worth observing on a few selected examples how and in what direction the theologization of Greek terms, which play an important role in the biblical message of the Septuagint and the New

20 Cf. Roberts, “The Language Background," 198. 
Testament, took place. Due to the limited size of this article, only five more characteristic terms will be discussed (and very briefly at that).

\section{a) agapē}

This noun deserves particular attention at this point, primarily because it does not appear at all in the extra-biblical Greek literature until the second century AD. Classical Greek knew only the noun agapessis ("affection"), ${ }^{21}$ but it was used very rarely. ${ }^{22}$ Even where philosophers considered the question of love between people, the subject of their reflection is not agape, but eros..$^{23}$ In their writings the theme of love of man for gods, or of gods for man does not appear. In their human imaginations, deities were beings endowed with numerous vices and evil inclinations, unsuitable for imitation and did not arouse a feeling of love in people. In turn, when the writers mentioned the "love" of a deity for man, they rather meant enjoying a special privilege granted by them. Also, the verb agapaō did not have a strictly defined meaning of its own in their writings but expressed a generally friendly approach to another person. So it meant: "loving someone," "showing affection," "liking something," "being satisfied with something," "showing someone respect." It also repeatedly appeared as a synonym of fileō ("to love," "to be friendly," "to show love," for example, with a kiss) or erao ("to love" in the sense of sexual love, "to desire"). ${ }^{24}$

God's love for man occupies an important place in the biblical books, and one of the most important commandments given to the chosen people is to love God with one's whole being (Deut 6:5). In the Hebrew texts, the noun 'ahabāh was used. To express this idea, unknown to the Greek world, the authors of the Septuagint used the noun agapesis in 12 places, but also introduced into the theological language the new noun agape ${ }^{25}$ However, it must be admitted that they still use this word quite rarely, since it appears only 19 times in the entire Septuagint, of which as many as 11 times in the Song of Songs. In this book, it expresses a tender and delicate love that cannot be bought with money, and at the same time similar to the heat of the fire and ready to make the greatest sacrifices. It is precisely this love between the bridegroom and the bride, in an allegorical interpretation, that became the image of God's sublime and never-ending love for his people. ${ }^{26}$ Apart from this book agape appears

21 Cf. Wischmeyer, "Vorkommen und Bedeutung von Agape," 212.

22 For example, in the works of Aristotle, the term agapessis appears only once (Metaphysics 980a). This is noted by Cambiano, "The Desire to Know," 3-4.

23 Cf. Flasza, "Grecka terminologia miłości," 237.

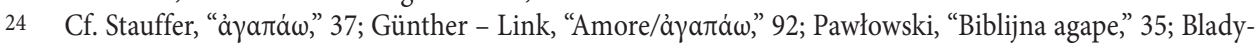
nic-Sośnierz, "Pojęcia wyrażające cnotę miłości," 81-86.

25 Some suppose that the noun agape was used in the colloquial speech of the Egyptians. Cf. Bladyniec-Sośnierz, "Pojęcia wyrażające cnotę miłości," 87. 
in 2 Sam 13:15, where it also expresses erotic love, in Eccl 9:1.6; Wis 6:17-18, where it denotes love in general as the greatest spiritual value of man, and in Wis 3:9; Jer 2:2, where it in turn describes man's love for God, which is a sign of fidelity to man's Savior.

The relatively rare use of both these terms (agapessis and agapē) in the Septuagint is mainly due to the fact that the Hebrew language, which was the basis of the Greek version of Scripture, is reluctant to use abstract nouns. Also, it prefers to describe love between people, God's love for the people, or people's love for God, by using verbs. It is noteworthy, however, that the authors of the Septuagint use the verb stergo for friendly love only once, the verb erao meaning sensual love only 3 times, the verb fileō only 33 times, and the verb agapaō referring to love between people and love between people and God in as many as 268 verses, with the last word being always used to describe God's love for man. It undoubtedly happened because, in the Greek vocabulary, the verb agapaō had a very general and neutral meaning that could be adapted to the solemn message of the Bible. For the same reason, the creators of the Septuagint coined the previously non-existing noun agape from this verb and gave it a meaning that was absent in the words commonly used to describe various manifestations of love between people. ${ }^{27}$

Jesus made from the commandment of love of God (Deut 6:5) and love of neighbor (Lev 19:18) two hinges of the entire Law and the Prophets (Matt 22:40), therefore love became one of the main topics in the teaching of the New Testament authors. Writing about it, they drew on the terminological heritage of the Septuagint but also enriched it with new reflections. They entirely removed the verbs stergo and erāo from their vocabulary because the subject of their teaching was not love as such, much less erotic love, but Christian love, which is rooted in God's law. Moreover, the word fileo was used quite rarely (it appears 25 times throughout the New Testament). They granted a distinctly privileged position to the verb agapaō (142 occurrences), and to the noun agape $\bar{e}$ alongside it. The latter term, in particular, was perfectly suited for expressing God's sublime love as it was free from any negative associations, which pagan words denoting love had. It is noteworthy that the noun agape appears extremely rarely in the Synoptic Gospels and the Acts of the Apostles (Matt - once; Luke - once), while in Corpus Paulinum it was used as many as 74 times, 30 in the writings of St. John, and 7 times in other New Testament epistles in relation to both God's love and the Christian notion of love between people.

This list shows that the reflection on love-agape was primarily developed by St. Paul and St. John. The cornerstone of St. Paul's teaching is the notion of truth whereby God Himself is the source of all the love in the human heart. His immeasurable love for his creations allows people to learn the sacrifice of the son of God who willingly gave up his life on the cross in order to beg redemption for sinners (Rom 5:6-11). However, He, whose nature contains love and peace (2 Cor 13:11),

27 Cf. Chmiel, "Biblijne pojęcie agape," 182; Guzewicz, "Miłość prawdziwa," 145. 
does not keep this attribute to Himself but pours love into the hearts of men through his Holy Spirit (Rom 5:5). This means that love is a gift of God which, at the same time, creates a commitment in the life of a Christian. Indeed, upon experiencing God's love, man should imitate Him and be guided by a sincere love devoid of hypocrisy throughout his life, treating others as his brothers. ${ }^{28}$ Similar truths are included in St. John's epistles, who proclaims that God is love, and He manifests it by sending His only born Son into the world. This means that those who have believed in Jesus Christ should have a brotherly love for one another, a love ready to make the greatest sacrifices (see especially 1 John 4:9-21). ${ }^{29}$ These and other truths related to them, which have already become the subject of many extensive scientific studies, were completely new to Greek readers and, in an astounding way, broadened their concept of love to include theological aspects about which no philosopher or poet had written for them so far. ${ }^{30}$

\section{b) hamartia}

The second idea that we will not find in the Hellenistic religious world is sin. In ancient Greek literature, there is of course a reflection on the evil that man perpetrates by breaking state laws, violating good manners, or harming other people in various ways. They were defined, among others, as kakia ("evil"), adikia ("harm"), adikèma ("transgression," "injustice"), anomia ("lawlessness"), as well as parabasis ("violation"). One example of such a reflection is the Nicomachean Ethics 1135b. In it, Aristotle considers four types of damage that can occur in transactions between people. These are: an unfortunate accident (atychèma), a mistake without malicious intent (hamartēma), an unjust act committed knowingly but without premediating (adikē$m a$ ), and an evil act committed based on a prior decision (kakia). This text uses the term hamartema, which (like hamartia) had appeared in Greek literature since the time of Homer with the meaning "error," "miss one's target," and from the 5th century BC it sometimes defines a mistake that does not result from ill will or deliberately breaking some laws, lack of something, missing one's target (when e.g. talking about an archer shooting at a target), mistake, missing something. In these texts, hamartia has no religious meaning and does not refer to divine commands. ${ }^{31}$

The authors of the Septuagint used fairly often the terms kakia, adikia, adikēma, anomia, or (less frequently) parabasis known to Greeks, to describe evil, crime, and harm. Although they had such an extensive vocabulary in this field, they ad-

28 There are many texts in which St. Paul conveys this teaching. Cf. i.a. Rom 12:9-21; 1 Cor 13:1-13; 16:14; 2 Cor 8:24; Gal 5:13; Eph 4:2; Phil 2:2; 1 Thess 5:13. Kazimierz Romaniuk writes on this subject, Motywacja napomnień moralnych, 86-97; Stasiak, "Miłość Boża," 161-179.

29 Cf. Chmiel, "Biblijne pojęcie agape," 183-187.

30 Cf. Guzewicz, "Miłość prawdziwa," 146.

31 Cf. Roberts, "Reconsidering Hamartia," 346-348. 
opted the terms hamartia and hamartèma from the Greek dictionary, giving them a new theological meaning. Using these words when referring to God brings a lot of new content to the Greek reflections on crime and evil. Beginning with the first chapters of the Book of Genesis, the biblical authors present God as the measure of everything, and therefore also the measure of good and evil. Therefore, when people act against His will, contained in His Holy Law and the teachings of the prophets (see, e.g. Num 32:23; Tob 3:5; Isa 1:4), when they are unfaithful to their covenant with Him and do not worship Him (Isa 30:1;43:24), they turn away from Him, worshiping dead idols (Exod 20:5; 32:21.30-34; Deut 9:18.21; 1 Kgs 12:30; Hos 8:11; Jer 16:10ff), they defile the worship performed in the sanctuary (1 Sam 2:17; Isa 1:14; Ezek 28:18), or they do evil and harm to other people (Gen 42:21; Num 5:6; Deut 19:15; Amos 5:12 and many others), then they "miss the target" which God set before them in the act of creation. ${ }^{32}$ Therefore, in the Septuagint hamartia and hamartèma take both the spiritual meaning of sin, which includes the distortion or even breaking of the relationship with God, and its social dimension, because the result of the destruction of a proper relationship with God is disorder in human relationships. This way, along with the teachings about the one true God, the Septuagint introduced the concept of sin into the religious beliefs of the Greeks, guilt against the King of all the earth, who upholds respect for human rights and well-being.

In the New Testament, the classical terms for crime or misdemeanor appear rarely, while hamartia and the related verb hamartano, which are used here only in the theological sense, undergo further development. In the Gospels and the Acts of the Apostles, hamartia appears most often in the context of ensuring that God or in His name Jesus forgives the sins of a converted man, thus granting him the gift of salvation (see e.g. Matt 9:2; 26:28; Luke 7:47-49; Acts 2:38; 3:19; 5:31 and others). In the epistles of St. Paul, on the other hand, it undergoes another transformation, because in his theological reflection he employs this term almost always in the singular (53 times out of 64). he describes with it not so much individual acts of man as the spiritual power which leaves its devastating imprint on the life of all humanity (see especially Rom 3:9; 5:12-13.20-21). ${ }^{33}$ In this manner of speaking, one can also notice the personification of sin, perhaps executed under the influence of the pictorial description in Gen 3. St. Paul resorts to this rhetorical figure, often employed by Greek writers, not to portray sin as a demonic person or power, which a powerless man (cf. Rom 5:6) cannot resist alone, but because with it, he is able to express better the truth about the sinful condition in which every single human being finds themselves. ${ }^{34}$

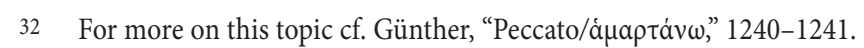

33 Cf. Penna, Lettera ai Romani, 213.

34 Cf. Fitzmyer, Romans, 331; Röhser, Metaphorik und Personifikation der Sünde, 103-143; Winger, "From Grace to Sin," 168-174.
} 
Thus, in the New Testament, the original meaning of the words hamartia and hamartanō (making an error or missing a target) completely disappears. Here they always have a theological meaning and denote the sin of a person who opposes God, commits wrongdoing or knowingly harms another person. Such sin introduces man into a state of spiritual death and creates a barrier between him and God that can only be destroyed by God through a merciful act of forgiveness. These and other ideas related to the concept of sin, present in the teaching of the New Testament, have until now been completely unfamiliar to pagan culture.

\section{c) diathēkē}

An important biblical institution that has no counterpart in the entire pagan world is God's covenant with the chosen people. This idea permeates all biblical history, from the story of Noah, described in Genesis 6-9, to the apocalyptic vision of St. John. Showing God's special relationship with Israel, the authors of the Hebrew Bible used the pattern of a two-way treaty between two states, larger groups of people, or two individuals. Such purely secular pacts also appear on the pages of the Bible, which shows that the social institution of covenant itself and its accompanying ritual were common knowledge in the ancient Near East. ${ }^{35}$

For the biblical authors, however, much greater importance is attached to the idea of God's covenant with the chosen people, which does not appear in the pagan world. Since while the religious Canaanite covenants were a contract that people offered to the gods, expecting prosperity and kindness from them in return for food sacrifices, ${ }^{36}$ the initiative in the biblical history came from God, who, out of love for his people, treating them as a privileged property, undertook to take special care of it, protect it from other nations and watch over its safe development, and called upon Israel to be faithful to its Savior and to observe His wise laws and commandments. This covenant, then, is a bilateral treaty that had important religious and moral consequences in the lives of the Israelites, as under its provisions, the chosen people were to worship the One who liberated them from Egyptian bondage as their only God and to obey His Law, which regulated all areas of social and private life. ${ }^{37}$

This covenant is referred to in the Hebrew Bible by the term berit, the etymology of which is still debated by linguists. In Greek, the term synthēkē was used to describe a similar bilateral agreement or political arrangement. The creators of the Septuagint knew it and applied it several times to agreements concluded between two nations (e.g. 1 Macc 10:26; 2 Macc 12:1; 13:25; Isa 30:1) and only the authors of the Book of

35 For more on this topic cf. Arndt, "Niektóre aspekty przymierza," 5-17; Jelonek, "Biblijne pojęcie przymierza," 181-184.

36 Cf. Jankowski, Biblijna teologia przymierza, 17.

37 Cf. Filipiak, "Przymierze," 150-152; Jelonek, "Biblijne pojęcie przymierza," 184-185. 
Wisdom, strongly influenced by Hellenistic culture ${ }^{38}$ and writing their reflections in Greek, used it once for the covenant of God (Wis 12:21). Since the word was entirely secular in the Hellenistic world, the authors of the translation preferred to use the term diathēke for the covenant made by God with His people. In Greek, it originally denoted disposing of property, a will, issuing a written instruction regarding one's property left behind after death. What is important in every will is that it is a unilateral agreement that can only be changed by its author. It is probably this feature that influenced the theological use of the term diathēke , although it did not fully overlap with the Hebrew berit. With its help, the authors of the Septuagint emphasized the truth that in all the covenants made by God with His chosen ones (both with Noah and Abraham, as well as with the entire people of Israel), the initiative came from God, and although it was a kind of two-way agreement, and man could accept or reject it, yet he could never change its content, which was constituted by God's laws and commandments. ${ }^{39}$ This truth is confirmed by St. Paul in Gal 3:14-15, where he returns to the original meaning of diathēkē.

New Testament writers, referring to the Greek version of the Bible, indicate that Jesus fulfilled the announcement of Jer 31:31 (in LXX: Jer 38:31; see Heb 8:8) and made a new covenant with his people (Luke 22:20; 1 Cor 11:25). The author of Heb 9:15-17 draws an in-depth reflection, combining the two meanings of diathēkē: secular - "a will" and biblical - "covenant." He notes that the death of Jesus was necessary to seal the new covenant contained in His blood, because it made it possible for people to enjoy His goods. His covenant, therefore, also has the dimension of a bequest, in which a dying person hands over the goods he has left behind his heir. According to the generally applicable custom, the heir has no right to change the will of the testator, and he may take ownership of the property only after his death. Those, therefore, who believed Christ and in Christ, after His salvific death and resurrection, according to His will, received the kingdom of heaven in inheritance (cf. Luke 22:29-30). ${ }^{40}$ Basing on this dual meaning of the term diathēke, St. Jerome rendered it in his translation using the word testamentum. In this way, he recorded the names Vetus Testamentum and Novum Testamentum, making it clear to the Latin readers that in the theological sense the term testamentum means both the covenant of God and the Son of God with His people, as well as the writings describing the history of both these covenants. ${ }^{41}$

\footnotetext{
38 Regarding this, see: Poniży, Księga Mądrości, 30.

39 Cf. Jankowski, Biblijna teologia przymierza, 16; Jelonek, "Biblijne pojęcie przymierza," 184.

40 Cf. Łach, “Testament czy przymierze?," 395; Malina, List do Hebrajczyków, 414-415.

41 In the translation of the Old Testament texts, St. Jerome translates berit as foedus or pactum, and he uses the word testamentum just in the translation of the books taken from Septuagint (instead of Greek diathēkē) and psalms.
} 


\section{d) ekklēsia}

In ancient Greece, an important political role was played by the plenary assembly of citizens, known as the ekklèsia. This noun comes from the verb ekkaleō, which means "to summon," "to evoke" and was used, to determine the procedure of convening such an assembly. In the constitutional government of the Greek city-state (polis), it was the supreme authority. In Athens, from $508 \mathrm{BC}$ to $322 \mathrm{AD}$, it was a strictly democratic institution in which all city citizens could participate, excluding foreigners, women and people without voting rights. ${ }^{42}$ Its competences included making decisions regarding the modification of the law, the selection of officials, concluding alliances, declaring war on someone, etc. ${ }^{43}$ During the Hellenistic period, ekklēsia retained its classic meaning as a gathering of citizens. It was still held in Athens but was no longer a democratic institution. Moreover, it was never religious in nature, although it began with prayers and sacrifices made to the patron gods of the city. Moreover, in the Greek world, the term ekklēsia was never used as a name for a religious group. ${ }^{44}$

This word radically changed its meaning in the Septuagint. Because the Old Testament authors view Israel in terms of theocracy, their writings do not mention political gatherings having a democratic character. On the other hand, they often write about the gathering of the people of Israel, convened to listen to the word of God (Deut 9:10; 18:16) and to worship the God of Israel (Judg 21:5; $1 \mathrm{Kgs}$ 8:14.22; 1 Chr 13:2.4; Ezek 10:1) or to gather troops for a military expedition led in the name of the Lord (Judg 20:2; 1 Sam 17:47). ${ }^{45}$ In the Hebrew Bible it is described with the term qāhāl, which the creators of the Septuagint translated as ekklessia. Thus, this word completely lost its political meaning in the Bible and became a technical term for a religious assembly, convened by God's own will (the exception is Jdt 6:16.21, where, under the influence of the Hellenistic culture, the author uses this term to describe a secular assembly convened by chiefs of cities). In addition to it, the Septuagint often uses the term synagōge, which in classical Greek meant a general assembly, and in the Bible it most often expresses the idea of Israel gathered by God into one nation (e.g. Exod 12:6; 19:47; 16:1-10; Lev 4:13-15; 8:3-5 and many others). ${ }^{46}$

In the New Testament this term undergoes increasing theologization. Some scholars suppose that it was originally used by the Jerusalem Hellenists, mentioned in Acts 6:1. Knowing it from the Septuagint, they borrowed its religious connota-

42 Cf. Ward, "Ekklesia," 164.

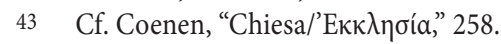

44 Cf. Ward, "Ekklesia," 165-166.

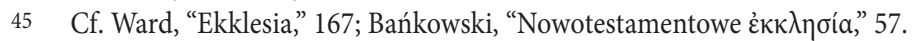

46 Sometimes, it also expresses the general idea of gathering certain things or people in one place (e.g. Gen 1:9; 1 Macc 3:44; Job 8:17) or it means a big crowd of people (Gen 28:3; 35:11; 48:4; Ps 7:8; 15:4 LXX). 
tion began to use it for meetings where Christians professed faith in the risen Jesus, pondered the teaching of the apostles and prayed together to God. ${ }^{47}$ They rejected the name synagoge eince at that time it was a technical term for both the Jewish community assembled for prayer and hearing the word of God, as well as a special building dedicated to such meetings. ${ }^{48}$ In fact, Christians of Jewish origin initially attended the synagogue on the Sabbath to pray with their fellow countrymen. Also St. Paul started his activity in every city with teaching in the synagogue. However, Christians were forced to separate themselves and organize their new cult in their own homes when those who rejected the Gospel began to openly oppose and persecute them. The epistles of St. Paul testify that they also called this liturgical assembly ekklessia (esp. 1 Cor 11:18.22; 14:4-35; Phlm 1:2). ${ }^{49}$

In the epistles of St. Paul, however, another very important stage in the development of this term is discernible. When each of the communities founded by the Apostle was developing, it was indispensable to choose superiors and specify various roles of people responsible for its proper functioning. Soon each such local community of Christians, having specific internal structures, also acquired the name ekklesia, in such a way that St. Paul in his letters could already address the Church of God (that is, the community of believers in God) in Corinth (1 Cor 1:2) and Galatia (Gal 1:2), or write about the various Churches which are in Macedonia (2 Cor 8:1), Asia (1 Cor 16:19) and Judea (1 Thess 2:14). In the further period of his activity, he noticed that all these local communities, although they live their own lives, together form one people of God, which professes the same faith in Jesus as Christ and the Savior of all mankind, and with Christ as the head they form one people of God, consisting of Christians of both Jewish and pagan origin. This idea is most evident in the Epistles to the Ephesians and Colossians, in which ekklessia becomes the sublime name for all believers in Christ the Savior, the universal Church uniting all mankind. ${ }^{50}$

47 Cf. Campbell, “The Origin and Meaning," 131; Trebilco, "Why Did the Early Christians," 440-441. George

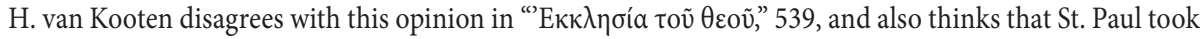
the name ekklessia from the Greek community and used it with reference to the Christian community to show that it reflects the activity of citizens' gatherings. A similar position is adapted also by Richard Last (“Ekklēsia," 959-980).

48 Cf. Ward, "Ekklesia," 169; Roberts, "The Meaning of 'Ekklesia," 35-36; Trebilco, "Why Did the Early Christians," 456. The similarities and differences between the synagogue and the Church are analyzed in detail by Wolfgang Schrage ("»Ekklesia« und »Synagoge«," 178-202). In the New Testament books only in Jas 2:2 synagoge e refers to the gathering of Christians. The author of this work applies such a term to "a church liturgical assembly in which Judeo-Christians gather together with baptized pagans." Kozyra, List świętego Jakuba, 129.

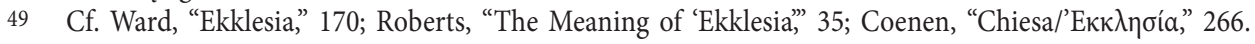

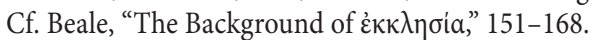

50 Cf. Ward, "Ekklesia," 171; Paciorek, Paweł Apostoł, 33. 


\section{e) eunouchos}

Finally, it is worth saying a few words about the very unusual theologization affecting the noun eunouchos and the verb related to it eunouchidzō. In Greek, the term eunouchos originally meant "a guardian of the bed." As the guardian of the harem was usually a eunuch, over time, this word began to denote a castrated man. While the verb eunouchidzō has always denoted the act of castration, the noun eunouchos was often also the title of a courtier, functioning independently of the act of physical mutilation. These two words retain this sense both in the Hellenistic environment as well as in the Septuagint (see e.g. Gen 39:1; 40:2,7; 1 Sam 8:15 and others) and in Acts 8:27-39.51

Therefore, it is strange that when Jesus speaks of the need of self-denial for the sake of the kingdom of heaven, He declares in Matthew 19:12 that there are eunouchoi who are born that way, eunouchoi whom men have made such (eunouchisthesan), and there are also eunouchoi who became such (eunouchisan) for the kingdom of heaven. The first category of people enumerated here refers to those who were born sterile whereas the second refers to castrated men. However, in the case of the third group there is a problem with the interpretation of the words used in the Gospel.

To properly understand this text, one should know first that ancient pagan literature portrayed eunuchs contemptuously as obese flatterers, effeminate men without a beard, despotic and cruel, ${ }^{52}$ and in a Jewish environment, where castration was forbidden under punishment, no man who has been physically mutilated could participate in the sacrificial cult (Lev 21:20; Deut 23:2). In this context, then, Jesus' statement cannot be understood as an exhortation to deprive oneself of masculinity. Some consider it a typical Semitic hyperbola, the same as the call to self-mutilate oneself in the fight against temptation in Matthew 5:29-30. ${ }^{53}$ It appears, however, that in this third category of people who have voluntarily become eunuchs for the kingdom of God, one should rather see a reference to the title functioning at the royal court (as in Acts 8:27-39). Moreover, in the use of the Greek word by the Evangelist to describe the act of becoming a eunuch, one can discern an unusual type of theologization which - due to drastic associations - was not undertaken by later Christian writers. It was owing to this that eunouchos acquired the form of a metaphor of celibacy and all radical self-sacrifices that can be made by a man who is completely focused on God and His reign in the world. ${ }^{54}$ By using the plural (eunouchoi), Jesus may also point to Himself and John the Baptist. Their example shows best how one can devote their whole life to God and His will to bring everyone to salvation..$^{55}$

Translated by Grzegorz Knyś

\footnotetext{
51 Cf. Hahn, "Circoncidere - evirare/عủvoũxoc," 295.

Blinzler, "Eisin eunouchoi," 257.

Cf. Bartnicki, "Pouczenie uczniów," 57.

Harvey, "Eunuchs for the Sake of the Kingdom," 13-14.

Schneider, "Eủvoũxoৎ," 766.
} 


\section{THEOLOGIZATION OF GREEK TERMS AND CONCEPTS}

\section{Bibliography}

Arndt, M.B., "Niektóre aspekty przymierza w Starym Testamencie," Quaestiones Selectae 11 (2000) 5-24.

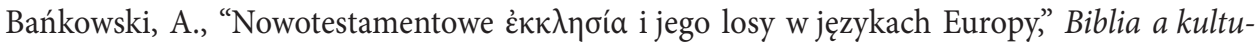
ra Europy (eds. M. Kamińska - E. Małek) (Łódź: Wydawnictwo Uniwersytetu Łódzkiego 1992) I, 57-63.

Bartnicki, R., "Pouczenie uczniów o dobrowolnej bezżenności (Mt 19,10-12)," Stworzył Bóg człowieka na swój obraz. Księga pamiątkowa dla Biskupa Profesora Mariana Gołębiewskiego w 65. rocznice urodzin (ed. W. Chrostowski) (Warszawa: Vocatio 2002) 53-58.

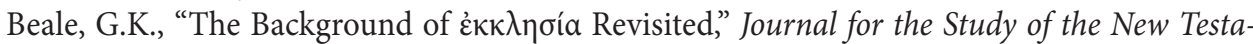
ment 38 (2015) 151-168.

Bertram, G., "Praeparatio Evangelica in der Septuaginta," Vetus Testamentum 7 (1957) 225-249.

Bielawski, M., Mikroteologie (Kraków: Homini 2008).

Bladyniec-Sośnierz, A.M., "Pojęcia wyrażające cnotę miłości w Biblii," Collectanea Theologica 87/1 (2017) 75-89.

Blinzler, J., “Eisin eunouchoi. Zur Auslegung von Mt 19,12," Zeitschrift für die Neutestamentliche Wissenschaft 48 (1957) 254-270.

Cambiano, G., "The Desire to Know (Metaphysics A 1)," Aristotle's Metaphysics Alpha. Symposium Aristotelicum (ed. C. Steel) (Oxford: Oxford University Press) 1-42.

Campbell, J.Y., "The Origin and Meaning of the Christian Use of the Word EKK $\Lambda \mathrm{H} \Sigma \mathrm{IA}$," Journal of Theological Studies 49 (1948) 130-142.

Chmiel, J., "Biblijne pojęcie agape jako model etyczny," Ruch Biblijny i Liturgiczny 30/4 (1977) 181-189.

Chrostowski, W., “"Gdy Bóg przemówił po grecku». Septuaginta jako świadectwo gruntownej transpozycji językowej," Poradnik Językowy 16/5 (2016) 60-70.

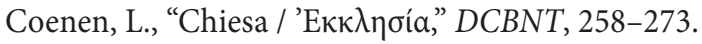

Coenen, L.- Beyreuther, E.- Bietenhard, H. (eds.) Dizionario dei concetti biblici del Nuovo Testamento, 4 ed. (Bologna: Edizioni Dehoniane 1989) (= DCBNT).

Deissmann, A., Bible Studies (Edinburgh: Clark 1901).

Ehrensperger, K., "Speaking Greek Under Rome: Paul, the Power of Language and the Language of Power," Neotestamentica 46/1 (2012) 9-28.

Filipiak, M., "Przymierze w Piśmie Świętym," Ruch Biblijny i Liturgiczny 25/3 (1972) 145-155.

Fitzmyer, J.A., Romans. A New Translation with Introduction and Commentary (New York: Doubleday 1993).

Flasza, A., "Grecka terminologia miłości. Preliminaria do dyskursu o miłości agape w Liście św. Pawła do Rzymian," Verbo Domini servire. Opuscula Ioanni Cantio Pytel septuagenario dedicata (eds. F. Lenort - T. Siuda) (Poznań: Uniwersytet Adama Mickiewicza 2000) 231-239.

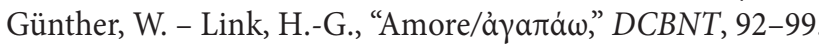

Günther, W., "Peccato/åua $\tau^{\prime \alpha} v \omega$, , DCBNT, 1240-1245.

Guzewicz, M., "Miłość prawdziwa. Refleksja na bazie analizy terminu «agape»," „Żyjemy dla Pana" (Rz 14,8). Studia ofiarowane siostrze Profesor Ewie J. Jezierskiej OSU (ed. W. Chrostowski) (Rozprawy i Studia Biblijne 23; Warszawa: Vocatio 2006) 141-150.

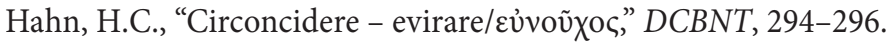


Harl, M., "La «Bible d’Alexandrie» et les études sur la Septante. Réflexions sur une première expérience," Vigiliae Christianae 47 (1993) 313-340.

Harvey, A.E., "Eunuchs for the Sake of the Kingdom," Heythrop Journal 48 (2007) 1-17.

Hemer, C.J., "Reflections on the Nature of New Testament Greek Vocabulary," Tyndale Bulletin 38 (1987) 65-92.

Jankowski, A., Biblijna teologia przymierza (Kraków: Tyniec 1997).

Jędrzejewski, S., "Septuaginta - Biblia helleńskiego judaizmu," Ruch Biblijny i Liturgiczny 58/4 (2005) 245-262.

Jelonek, T., “Biblijne pojęcie przymierza," Polonia Sacra 9/16 (2005) 181-197.

Joosten, J., "Pillars of the Sacred: Septuagint Words Between Biblical Theology and Hellenistic Culture," Svensk Exegetisk Årsbok 83 (2018) 1-15.

Kittel, G. - Friedrich, G. (eds.), Theologische Wörterbuch zum Neuen Testament (Stuttgart: Kohlhammer 1933-1979) I-IX (= TWNT).

Kozyra, J., List świętego Jakuba. Wstęp, przekład z oryginału, komentarz (Nowy Komentarz Biblijny. Nowy Testament 16; Częstochowa: Edycja Świętego Pawła 2011).

Last, R., "Ekklēsia outside the Septuagint and the Démos: The Titles of Greco-Roman Associations and Chris-Followers' Groups," Journal of Biblical Literature 137 (2018) 959-980.

Law, T.M., When God Spoke Greek. The Septuagint and the Making of the Christian Bible (Oxford: Oxford University Press 2013).

Lemański, J., “Pnp 8,5-7 jako próba zdefiniowania miłości?," Zeszyty Naukowe KUL 50/4 (2007) 31-48.

Lust, J., "Translation Greek and the Lexicography of the Septuagint," Journal for the Study of the Old Testament 59 (1993) 109-120.

Łach, S., “Testament czy przymierze?," Łach S., List do Hebrajczyków. Wstęp - przekład z oryginału, komentarz - ekskursy (Pismo Święte Nowego Testamentu 10; Poznań: Pallottinum 1959) 383-395.

Malina, A., List do Hebrajczyków. Wstęp, przekład z oryginału, komentarz (Nowy Komentarz Biblijny. Nowy Testament 15; Częstochowa: Edycja Świętego Pawła 2018).

Mazurkiewicz, P., “Teologizacja narodu czy nacjonalizacja Kościoła? Koncepcja narodu w nauczaniu kardynała Stefana Wyszyńskiego," Saeculum Christianum 9/2 (2002) 267-276.

Mickiewicz, F., Teologiczna etyka Świętego Pawła (Częstochowa: Edycja Świętego Pawła 2017).

Mohrmann, Ch., "Linguistic Problems in the Early Christian Church," Vigiliae Christianae 11 (1957) 11-36.

Nock, A.D., “The Vocabulary of the New Testament," Journal of Biblical Literature 52 (1933) 131-139.

Paciorek, A., Paweł Apostoł - pisma (Tarnów: Biblos 1996) II.

Pawłowski, Z., "Biblijna agape. Język miłości i jego funkcja w kształtowaniu społecznego wymiaru doświadczania Boga," Ethos 11/3 (1998) 33-49.

Penna, R., Lettera ai Romani. Introduzione, versione, commento (Bologna: Edizioni Dehoniane 2010).

Piętka, R., "Antyczna translatologia," Pamiętnik Literacki 95/1 (2004) 7-18.

Poniży, B., "Logos w Księdze Mądrości (18,14-16): między personifikacją a teologizacją," Zeszyty Naukowe KUL 40/1-2 (1997) 75-92. 
Poniży, B., Księga Mądrości. Wstęp, przekład z oryginału, komentarz (Nowy Komentarz Biblijny. Stary Testament 20; Częstochowa: Edycja Świętego Pawła 2012).

Rajak, T., Translation and Survival. The Greek Bible of the Ancient Jewish Diaspora (Oxford: Oxford University Press 2009).

Roberts, E., "Reconsidering Hamartia as 'Sin' in 1 Corinthians," Method and Theory in the Study of Religion 26 (2014) 340-364.

Roberts, J.W., "The Language Background of the New Testament," Restoration Quarterly 5 (1961) 193-204.

Roberts, J.W., “The Meaning of 'Ekklesia' in the New Testament," Restoration Quarterly 15 (1972) 27-36.

Röhser, G., Metaphorik und Personifikation der Sünde. Antike Sündenvorstellungen und paulinische Hamartia (Tübingen: Mohr Siebeck 1987).

Romaniuk, K., Motywacja napomnień moralnych w listach św. Pawła (Poznań: Księgarnia św. Wojciecha 1971).

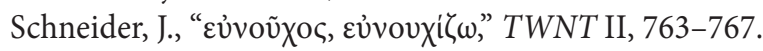

Schrage, W., "»Ekklesia« und »Synagoge«. Zum Ursprung des urchristlichen Kirchenbegriffs," Zeitschrift für Theologie und Kirche 60 (1963) 178-202.

Sobański, R., "Wprowadzenie do zagadnienia roli prawa w Kościele," Prawo Kanoniczne 18/1-2 (1975) 3-24.

Stasiak, S., “Miłość Boża rozlana w sercach naszych (Rz 5,5)," Verbum Vitae 23 (2013) 161-180.

Stauffer, E., “ảyatáa,” TWNT I, 20-55.

Szydłowski, P., “Teologizacja pedagogiki w twórczości Jacka Woronieckiego (1878-1949),” Filozofia i czas przeszły. Profesorowi Czesławowi Głombikowi w 70. rocznicęurodzin (eds. B. Szostek - A.J. Noras) (Katowice: Wydawnictwo Uniwersytetu Śląskiego 2005) 210-216.

Tabachovitz, D., Die Septuaginta und das Neue Testament (Lund: Gleerup 1956).

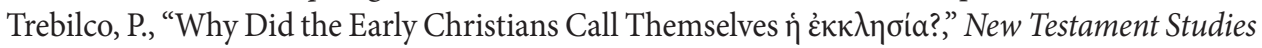
57 (2011) 440-460.

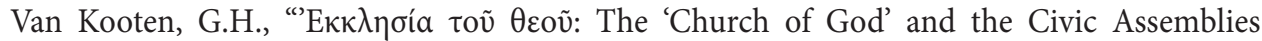
( $\dot{\varepsilon} \kappa \kappa \lambda \eta \sigma i ́ a)$ of the Greek Cities in the Roman Empire: A Response to Paul Trebilco and Richard A. Horsley," New Testament Studies 58 (2012) 522-548.

Ward, R.B., "Ekklesia: A Word Study," Restoration Quarterly 2 (1958) 164-179.

Winger, M., "From Grace to Sin: Names and Abstractions in Paul's Letters," Novum Testamentum 41 (1999) 145-175.

Wischmeyer, O., "Vorkommen und Bedeutung von Agape der außerchristlichen Antike", Zeitschrift für die neutestamentliche Wissenschaft und die Kunde der älteren Kirche 69 (1978) 212-238. 
